Int. J. Environ. Res. Public Health 2008, 5(5) 337-341

International Journal of

Environmental Research and Public Health

ISSN 1661-7827

www.ijerph.org

(C) 2008 by MDPI

\title{
Preclinical Assessment of Vernonia amygdalina Leaf Extracts as DNA Damaging Anti-cancer Agent in the Management of Breast Cancer
}

\author{
Clement Yedjou $^{1}$, Ernest Izevbigie $^{2}$ and Paul Tchounwou ${ }^{1}$ \\ ${ }^{1}$ Cellomics and Toxicogenomics Research Laboratory, NIH-RCMI Center for Environmental Health, 1400 Lynch Street, P.O. \\ Box 18540, Jackson, MS, USA \\ ${ }^{2}$ Cellular Signalling, Phytoceuticals, Cancer Prevention and Therapies, College of Science, Engineering and Technology, \\ Jackson State University, 1400 Lynch Street, P.O. Box 18540, Jackson, Mississippi, USA \\ "Correspondence to Dr. Clement Yedjou. E-mail: clement.g.yedjou@jsums.edu
}

Received: 18 September 2008 / Accepted: 05 December 2008 / Published: 31 December 2008

\begin{abstract}
Breast cancer is the leading cause of death among women between 40 and 55 years of age and is the second overall cause of death among women. Fortunately, the mortality rate from breast cancer has decreased in recent years due to an increased emphasis on early detection and more effective treatments. Despite early detection, conventional and chemotherapeutic methods of treatment, about $7 \%$ of women still died every year. Hence, the aim of the present study was to assess the therapeutic efficacy of vernonia amygdalina (VA) leaf extracts as anti-cancer agent against human breast cancer in vitro using the MTT [3-(4, 5-dimethylthiazol-2-yl)-2,5-diphenyltetrazolium bromide] and alkaline single cell gel electrophoresis (Comet) assays, respectively. In this experiment, human breast adenocarcinoma (MCF-7) cells were treated with different doses of VA leaf extracts for 48 hours. Data obtained from the MTT assay showed that VA significantly $((\mathrm{P}<0.05)$ reduced the viability of MCF-7 cells in a dose-dependent manner upon 48 hours of exposure. Data generated from the comet assay also indicated a slight dose-dependent increase in DNA damage in MCF-7 cells associated with VA treatment. We observed a slight increase in comet tail-length, tail arm and tail moment, as well as in percentages of DNA cleavage at all doses tested, showing an evidence that VA-induced minimal genotoxic damage in MCF-7 cells. Taken together, our findings suggest that VA treatment moderately $(\mathrm{P}<$ $0.05)$ reduces cellular viability and induces minimal DNA damage in MCF-7 cells. These findings provide evidence that VA extracts represent a DNA-damaging anti-cancer agent against breast cancer and its mechanisms of action functions, at least in part, through minimal DNA damage and moderate toxicity in tumors cells.
\end{abstract}

Keywords: Vernonia amygdalina; MCF-7 cells; cytotoxicity; genotoxicity; DNA damage.

\section{Introduction}

Medicinal plants have served as valuable starting materials for drug development in both developing and developed countries. Today, more than 80 per cent of the people living in Africa depend on medicinal plants and animal based medicines to satisfy their healthcare requirements. Vernonia amygdalina (family of asteraceae) is a valuable medicinal plant that is widespread in East and West Africa [1,2]. It is known as bitter leaf and may be used as active anticancer agent [3], anti-bacteria, antimalaria, and anti-parasites [4]. This plant contains complex active components that are pharmacologically useful. The roots and the leaves are used in ethnomedicine to treat fever, hiccups, kidney problems, and stomach discomfort $[2,5]$. The stem and root divested of the bark are used as chew-sticks in many West Africa countries like Cameroon, Ghana, and Nigeria. Vernonia amygdalina (VA) leaves are one of the most widely leaf vegetables (ndole or bitter leaf) consumed by Cameroonians during special occasions such as marriages, baptisms, Christmas, and birthday. Pharmacological studies have also shown that the leaf extracts have both hypoglycaemic and hypolipidaemic properties in experimental animals and so could be used in managing diabetes mellitus [6]. Traditional medical practitioners, herbalists, and local 
healers in West Africa recommend aqueous VA for their patients. The beneficial use of VA in animal nutrition in Nigeria has been well documented [7, 8]. Iwalokun reported that VA leaf extract enhanced the prophylactic and therapeutic efficacy of chloroquine against Plasmodium berghei malaria in mice [9].

Although published studies indicate that VA has medicinal properties effective against many diseases other than breast cancer, the molecular mechanisms under which this compound exerts its therapeutic effect in cancer cells remain largely unknown. Few reports indicate that extracts from plants are able to inhibit and even reverse carbon tetrachloride-induced hepatotoxicity in mice and rats $[10,11]$. Therefore, the aim of the present study was to use human breast adenocarcinoma (MCF-7) cells as test model to evaluate the cytotoxic and genotoxic efficacy of VA leaf extract in the management of breast cancer.

\section{Materials and Methods}

\section{Chemicals and Media}

Growth medium RPMI 1640 containing $1 \mathrm{mmol} / \mathrm{L} \mathrm{L}-$ glutamine was purchased from Gibco BRL products (Grand Island, NY). Fetal bovine serum (FBS), phosphate buffered saline (PBS) and other chemicals were obtained from Sigma Chemical Company (St. Louis, MO).

\section{Vernonia Amygdalina Preparation}

Pesticide-free fresh Vernonia amygdalina (VA) leaves, collected in Benin City, Nigeria, were rinsed with cold, distilled water. The leaves were soaked in cold water $(1: 1 \mathrm{w} / \mathrm{v})$ overnight at $4^{\circ} \mathrm{C}$ before being crushed by a gentle means to a mixture. The mixture was then filtered through clean white gauze to remove particulate matter before filtration through a 0.45 um filtration unit for sterilization. The resulting solution was lyophilized ( $5 \mathrm{~g}$ ) and stored at $-20^{\circ} \mathrm{C}$. Izevbigie has previously described this method of VA preparation [3].

\section{Cell Culture}

The human breast adenocarcinoma (MCF-7) cell line, purchased from the American Type Culture Collection ATCC (Manassas, VA), were thawed by gentle agitation of their containers (vials) for 2 minutes in a water bath at $37^{\circ} \mathrm{C}$. After thawing, the content of each vial was transferred to a $75 \mathrm{~cm}^{2}$ tissue culture flask, diluted with RPMI 1640 supplemented with $10 \%$ fetal bovine serum (FBS) and $1 \%$ penicillin and streptomycin, and incubated for 2 to 3 days at $37^{\circ} \mathrm{C}$ in a $5 \% \mathrm{CO}_{2}$ incubator. The growth medium was changed twice weekly. Cells grown to $75-85 \%$ confluence were washed with phosphate buffer saline (PBS), trypsinized with $3 \mathrm{~mL}$ of $0.25 \%$ (v) trypsin$0.0 .3 \% / \mathrm{v}$ ) EDTA, diluted with fresh medium, and counted using a hemacytometer.

\section{Cell Viability Assay}

In the experiment, $1 \times 10^{4}$ cells were plated in each well of 96-well plates, and were placed in the humidified $5 \% \mathrm{CO}_{2}$ incubator at $37^{\circ} \mathrm{C}$ to allow them to attach to the substratum for 2 to 3 days. The cells were exposed to different concentrations of VA leaf extracts and placed in the humidified $5 \% \quad \mathrm{CO}_{2}$ incubator for 48 hours. The cells incubated in culture medium alone served as a control for cell viability (untreated wells). Cell viability was determined using the MTT assay as previously described [12-14].

\section{Cell Treatment for Comet/Genotoxicity Assay}

Cells were counted $(10,000$ cells/well) and aliquots of $100 \mu \mathrm{L}$ of the cell suspension were placed in each well of 96 plates, treated with $100 \mu \mathrm{l}$ aliquot of either media or VA leaf extract $(0,0.5$, and $2 \mathrm{mg} / \mathrm{mL})$ respectively and incubated in a $5 \% \quad \mathrm{CO}_{2}$ at $37^{\circ} \mathrm{C}$ for $48 \mathrm{hrs}$. After incubation, the cells were centrifuged, washed with PBS free calcium and magnesium, and re-suspended in $100 \mu \mathrm{L}$ PBS. In a $2 \mathrm{~mL}$ tube, $50 \mu \mathrm{L}$ of the cells suspension and $500 \mu \mathrm{L}$ of melted LMAgarose were mixed and $75 \mu \mathrm{L}$ was pipetted onto a pre-warmed cometslide. The side of the pipette tip was used to spread completely agarose/cells over the sample area. The slides were placed flat in the dark at $4^{0} \mathrm{C}$ for 10 minutes to allow the mixture to solidify and then immersed in prechilled lysis solution at $4^{0} \mathrm{C}$ for 40 minutes. The slides were removed from lysis solution, tapped, and immersed in Alkaline Solution for 40 minutes at room temperature in the dark. The slides were washed twice for 5 min with Tris-Borate-EDTA (TBE). The slides were electrophoresed at low voltage $\left(300 \mathrm{~mA}, 25 \mathrm{~V}, 4^{0} \mathrm{C}\right)$ for 20 minutes. The slides were placed in $70 \%$ ethanol for 5 min, removed, tapped, and air-dried for overnight. The slides were stained with SYBR Green stain designed for the Comet Assay, and allowed to air dry at room temperature for six hours. SYBR Green stained cometslides were viewed with an Olympus fluorescence microscope and analyzed using LAI's Comet Assay Analysis System software (Loates Associates, Inc. Westminster, MD).

\section{Statistical Analysis}

The data from three experiments were pooled and the mean \pm SD values were calculated. The Least Significant Difference (LSD) obtained from ANOVA Dunnett's test was used to determine statistical differences between the control cells and VA-treated MCF-7 cells. All p-values $<0.05$ were considered to be significant.

\section{Results}

\section{Cytotoxic Efficacy of Vernonia amygdalina}

Human breast adenocarcinoma (MCF-7) cells were incubated with different concentrations of Vernonia 
amygdalina (VA) leaf extract $(0.125$ to $2 \mathrm{mg} / \mathrm{mL})$ for $48 \mathrm{~h}$. After incubation, cell viability was determined by the means of MTT [3-(4, 5-dimethylthiazol-2-yl)-2, 5diphenyltetrazolium bromide] assay. The viability of control cells was designated as $100 \%$, and the others were expressed as percent compared to the control. As shown in (Figure 1), there was a slight gradual decrease in cell viability and reached statistical significance $(P<0.05)$ at 1 and $2 \mathrm{mg} / \mathrm{mL}$ of VA leaf extract treatment. These data showed that VA leaf extracts caused moderate cytotoxicity to human breast cancer (MCF-7) cells, suggestive it's potential for preventing breast cancer.

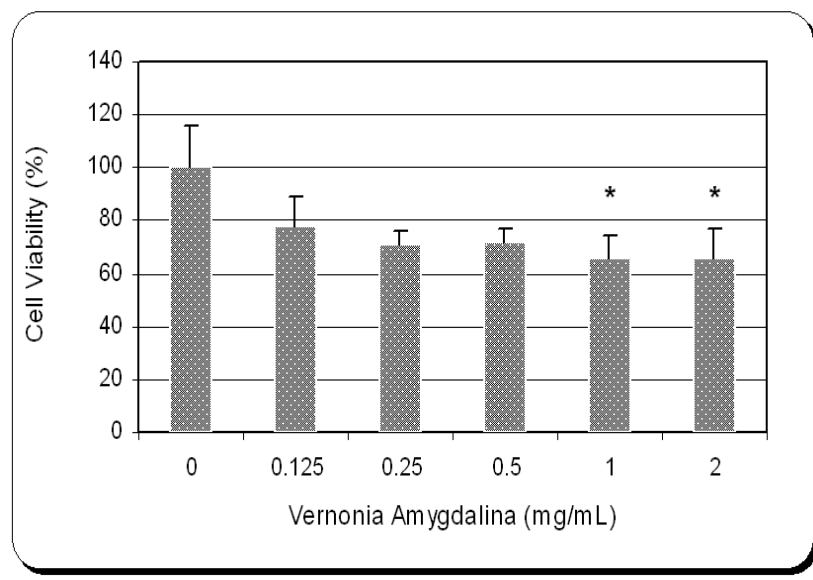

Figure 1: Cytotoxic Efficacy of Vernonia amygdalina (VA) leaf extracts to human breast adenocarcinoma (MCF7) cells. MCF-7 cells were cultured with different doses of VA for 48 hours as indicated in the Materials and Methods. Cell viability was determined based on the MTT assay. Each point represents a mean \pm SD of 3 experiments with 6 replicates per dose. *Significantly different $(p<0.05)$ from the control, according to the Dunnett's test.

\section{Genotoxic Efficacy of Vernonia amygdalina}

Representative images of comet cells untreated as control and Vernonia amygdalina (VA) leaf extractstreated cells using SYBR Green stain are presented in (Figure 2). As shown in this figure, there is minimal DNA damage in VA leaf extracts-treated MCF-7 cells compared to the control cells with significant difference at high dose $(2 \mathrm{mg} / \mathrm{mL})$ of exposure. Data generated from these studies showed slight gradual increase in the mean values of comet tail length, tail moment, arm tail, and percentages of DNA cleavage of MCF-7 cells, with increasing doses of VA leaf extracts. After 48 hours treating, the percentages of DNA cleavage mean values were $(1.4 \pm 1.6) \%,(2.2 \pm$ $1.6) \%$, and $(4.9 \pm 3.3) \%$ in $0,0.5$, and $2 \mathrm{mg} / \mathrm{mL}$ of VA leaf extracts respectively, showing a clear evidence that VA causes minimal DNA damage in a dose-dependent manner. So far, this technique has turned out to be a valuable tool for evaluating DNA damage in MCF-7 cells exposed to VA leaf extracts.

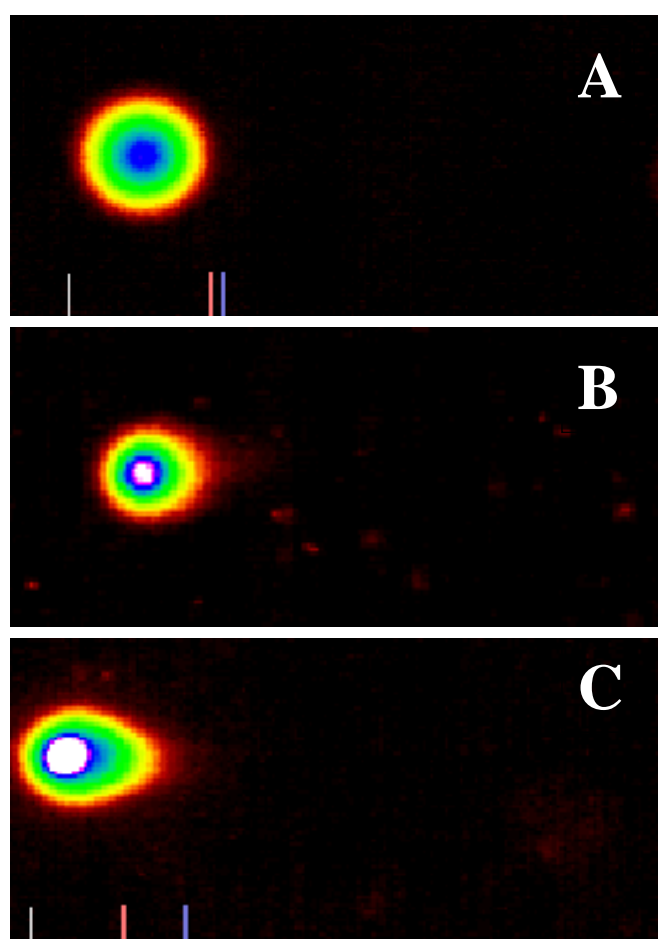

Figure 2: Representative SYBR Green Comet assay images of untreated (A-control) and VA leaf extractstreated MCF-7 cells at $0.5 \mathrm{mg} / \mathrm{mL}$ (B), and $2 \mathrm{mg} / \mathrm{mL}$ (C).

\section{Discussions}

\section{Cytotoxic Efficacy of Vernonia amygdalina}

Vernonia amygdalina (family of asterceae) is a valuable medicinal plant that is widespread in East and West Africa [1, 2]. Vernonia amygdalina (VA) leaf extracts have been used in various folk medicines as remedies against helminthic, protozoal and bacterial infections with subsequent scientific supports to these claims [4]. In the present study, we assessed the cytotoxic efficacy of VA leaf extracts using the MTT assay. Data generated from this assay strongly suggest that VA leaf extracts are moderately cytotoxic to MCF-7 cells even at high doses of exposure. VA leaves consumed in many Africa countries may be relatively toxic if consumed in large quantities, which is very unlikely. For example, the consumption of VA at $0.04-0.08$ of body weight did not cause any cytotoxic effects in 5-6 weeks of male abino rats [15]. To extrapolate, since the average body weight is about $70 \mathrm{~kg}$, it will require the consumption of 0.028 $0.056 \mathrm{~kg}(28-56 \mathrm{~g}) \mathrm{VA}$ in the body. Based on these data, we believe that the incorporation of VA in diet may help prevent or reduce the risk of breast cancer and other diseases considering the diverse applications of the plant in almost all African populations. Study by Tekobo and his colleagues indicated that oral administration of the aqueous leaf extract of the plant relieve pain and lower body temperature [16]. 


\section{Genotoxic Efficacy of Vernonia amygdalina}

By means of the comet assay, we elucidated in the present study some of the molecular changes in MCF-7 cells exposed to Vernonia amygdalina (VA) leaf extracts (Figure 3). Our results demonstrated that VA leaf extracts induce minimal DNA damage in MCF-7 cells in a dosedependent fashion, suggestive clear evidence that VA leaves may be a potent DNA damaging anti-cancer agent effective against breast cancer.

(A)

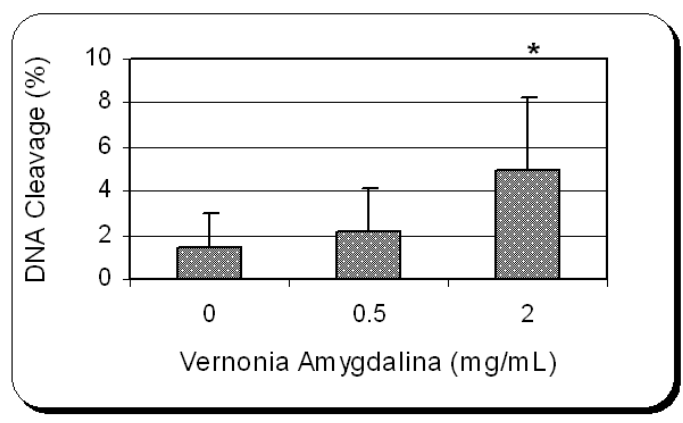

(B)

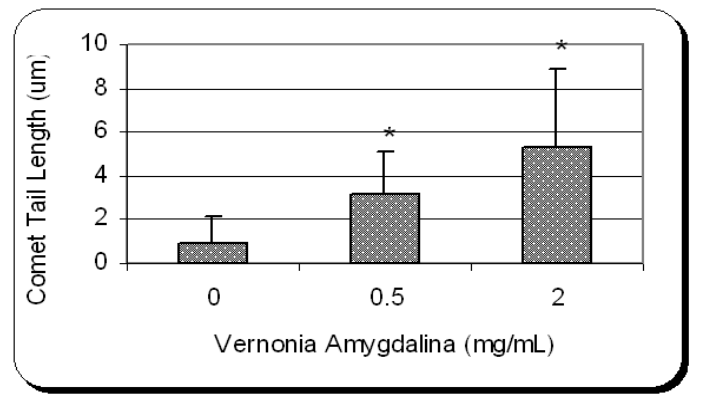

Figure 3: Comet assay of MCF-7 cells showing the percentage of DNA cleavage (Left) and tail length (Right), as a function of VA leaf extracts doses. Each point represents mean $\pm \mathrm{SD}$ of 3 independent experiments. *Significantly different $(p<0.05)$ from the control, according to the Dunnett's test.

The genotoxic induction by VA leaf extracts were minimal at higher dose $(2 \mathrm{mg} / \mathrm{mL})$ of exposure with mean value of DNA cleavage of equal or least than $5 \%$ and mean value for comet tail length of $5.3 \pm 3.6$ um (Figure 3A, 3B). As seen in the dose-response experiments of the present study, the extent of DNA damage increased proportionately with increasing doses of VA (Figure 3A, $3 \mathrm{~B})$. No data was found in the literature regarding the genotoxic effect of VA in vitro. In this article we document for the first time the effectiveness of the alkaline single cell gel electrophoresis (Comet) assay to evaluate DNA damage in MCF-7 cells following exposure to VA leaf extracts. Our results obtained from this assay provide evidence that VA represents a DNA-damaging anticancer agent against breast cancer and its mechanisms of action functions, at least in part, through minimal DNA damage and moderate toxicity in tumors cells. It has been reported that agents that have the ability to cause minimal DNA damage are generally good candidates for cancer therapy $[17,18]$. On the other hand, agents that cause cell damage but not cell death, causes sustained DNA damage, and are therefore possible mutagens and/or carcinogens $[19,20]$. Recent studies in our laboratory indicate that the pharmacology of arsenic trioxide as an effective anticancer drug is associated with its cytotoxic and genotoxic effects in human leukemia cells. We reported that arsenic trioxide caused less than $5 \%$ of DNA damage at 2.5 $\mu \mathrm{g} / \mathrm{mL}$ of exposure, suggestive that low doses of arsenic trioxide induce minimal DNA damage in HL-60 cells [21]. Previous study conducted by Izevbigie demonstrated that the treatment of MCF-7 cells with physiologically concentrations of water-soluble VA significantly inhibited DNA synthesis in a dose-dependent fashion [3].

\section{Conclusion}

The present study demonstrated that Vernonia amygdalina $(\mathrm{VA})$ leaf extracts slightly $(\mathrm{P}<0.05)$ reduce cellular viability and induce minimal DNA damage in MCF-7 cells as assessed by MTT and alkaline single cell gel electrophoresis assays, respectively. These in vitro findings provide the pharmacological support that VA represents a potential DNA-damaging anticancer agent against breast cancer and its mechanisms of action functions, at least in part through, minimal DNA damage and moderate toxicity in tumors cells. Because VA causes minimal DNA damage, it is therefore a good candidate for cancer therapy.

Acknowledgements: This research was financially supported in part by a grant from the National Institutes of Health (Grant No. 1G12RR13459), through the RCMICenter for Environmental Health, and in part by the National Center for Minority Health Disparities (Grant N0. P20MD000534-01) at Jackson State University. The authors thank Dr. Abdul Mohamed: Dean Emeritus and Dr. Mark Hardy: Dean of College of Science, Engineering, and Technology for their technical support in this research.

\section{References}

1. Ainslie, J. R.: List of plants used in native medicine in Nigeria. Imperial Forestry Institute: Oxford, UK, 1973; p. 42.

2. Burkill, H. M.: The useful plants of West tropical Africa. $2^{\mathrm{d}}$ ed.; Kew. England: Royal Botanical Gardens. 1985; Vol 1.

3. Izevbigie, E. B.: Discovery of water-soluble anticancer agents (edotides) from a vegetable found in Benin City, Nigeria. Exp. Biol. Med. 2003, 228, 293-298.

4. Tadesse, A.; Gebre-Hiwot, A.; Asres, K.; Djote, M.; Frommel, D.: The in vitro activity of Vernonia 
amygdalina on Leishmania aethiopica. Ethiop. Med. J. 1993, 31,183-189.

5. Hamowia, A. M.; Saffaf, A. M.: Pharmacological studies on Vernonia amygdalina (Del) and tithonia diversifolia (Gray). Vet. Med. J. 1994, 2, 91-97.

6. Akah, P. A.; Okafor, C. I.: Hypoglycaemic effect of vernonia amygdalina Del, in experimental rabbits. Plant Med. Res. 1992, 1, 6-10.

7. Onwuka, C. F. I.; Akinsoyinu, A. O.; Tewe, O. O.: Feed value of some Nigerian browse plants: chemical composition and in vitro digestibility. East African Agriculture and Forestry J. 1989, 54, 157-163.

8. Aregheore, E. M. K.; Makkar, H. P. S.; Becker, K.: Feed value of some browse plants from the central zone of Delta State. Nig. Trop. Sci. 1998, 38, 97-104.

9. Iwalokun, B. A.: Enhanced antimalarial effects of chloroquine by aqueous Vernonia amygdalina leaf extract in mice infected with chloroquine resistant and sensitive. Plasmodium berghei strains. Afr. Health Sci. 2008, 8, 25-35.

10. Ijeh, L.; Nwugo, V. O.; Obidoa, O.: Comparative studies on the nutritive Phyto-chemical and antimicrobial properties of two varieties of Vernomia amygdalina. Plant Pros. Res. Comm. 1996, 1, 71-75.

11. Babalola, O. O.; Anetor, J. I.; Adeniyi, F. A.: Amelioration of carbon tetrachlorine-induced hepatotoxicity by terpenoid extract leaves of Vernonia amygdalina, Afr. J. Med. Sci. 2001, 30, 91-3

12. Mosmann, T.: Rapid colorimetric assay for cellular growth and survival: applications to proliferation and cytotoxicity assays, J. Immunol. Method. 1983, 65, 55-63.

13. Tchounwou, P. B.; Yedjou, C. G.; Dorsey, W. C.: Arsenic Trioxide-Induced Transcriptional Activation and Expression of Stress Genes in Human Liver
Carcinoma Cells $\left(\mathrm{HepG}_{2}\right)$. Cell. Mol. Biol. 2003, 49, 1071-1079.

14. Yedjou, C. G.; Rogers, C.; Brown, E.; Tchounwou, P. B.: Differential effect of ascorbic acid and nacetyl-1-cysteine on arsenic trioxide mediated oxidative stress in human leukemia (HL-60) cells. $J$. Biochem. Mol. Toxicol. 2008, 22, 85-92.

15. Adaramoye, O.; Ogyngbenro, B.; Anyaegou, O.; Fafunso, M.: Protective effects of extracts of vernonia amygdalina, hisbicus. sabdaiffa and vitamin $\mathrm{C}$ against radiation-induced liver damage in rats. J. Radiat. Res. 2008, 49,123-131.

16. Tekobo, A. M.; Onabanjo, A. O.; Amole, O. O.; Emeka, P. M.: Analgesic and antipyretic effects of the aqueous extract of Vernonia amygdalina. West Afri. J. Pharm. 2002, 16, 68-74.

17. Hsiang, Y. H.; Lihou, M. G.; Liu, L. F.: Arrest of replication forks by drug-stabilized topoisomerase IDNA cleavable complexes as a mechanism of cell killing by camptothecin. Cancer Res. 1989, 49, 5077-5082.

18. Zhang, H.; D'Arpa, P.; Liu, L. F.: A model for tumor cell killing by topoisomerase poisons. Cancer Cells. 1990, 2, 23-27.

19. Toxicological profile for arsenic (update). Agency for Toxic Substances and Disease Registry: Atlanta, GA. 1999.

20. Wei, M.; Wanibuchi, H.; Yamamoto, S.; Li, W.; Fukushima, S.: Urinary bladder carcinogenicity of dimethylarsinic acid in male F344 rats. Carcinogenesis. 1999, 20, 1873-1876.

21. Yedjou, C. G.; Tchounwou, P. B.: In vitro cytotoxic and genotoxic effects of arsenic trioxide on human leukemia (HL-60) cells using the MTT and alkaline single cell gel electrophoreis (comet) assays. Mol Cell Biochem. 2007, 301, 123-130. 